http://jmscr.igmpublication.org/home/ ISSN (e)-2347-176x ISSN (p) 2455-0450 crossref DOI: https://dx.doi.org/10.18535/jmscr/v7i8.02

Journal Of Medical Science And Clinical Research

\title{
Skeletal Metastasis in Carcinoma Gallbladder
}

\author{
Authors \\ Dr Satyendra Narayan Sinha ${ }^{1 *}$, Dr Madhulika ${ }^{2}$, Dr Manisha Singh ${ }^{3}$ \\ ${ }^{1}$ Radiation Oncology Department, Paras HMRI Hospital, Patna (India) \\ ${ }^{2}$ Medical Oncology Department, Mahavir Cancer Sansthan, Phulwarisharif, Patna (India) \\ ${ }^{3}$ Head, Medical Oncology Department, Mahavir Cancer Sansthan, Phulwarisharif, Patna (India) \\ *Corresponding Author \\ Dr Satyendra Narayan Sinha \\ Radiation Oncology Department, Paras HMRI Hospital, Patna (India)
}

\begin{abstract}
Gallbladder carcinoma is the 5th most common gastrointestinal tract cancers and is an aggressive malignancy with varied presentation. The predominant sites of mestatasis being liver and regional lymph nodes. Skeletal metastasis in gallbladder carcinoma is very rare and only 15 cases have been reported in English literature so far. In this manuscript, we describe our experience of two cases of skeletal metastasis in carcinoma gallbladder.
\end{abstract}

Keywords: Gallbladder Cancer, Skeletal Metastasis in Gallbladder Cancer, Bony Metastasis.

\section{Introduction}

Gallbladder cancer is the most common of all the biliary tract cancers and is fifth most common of the gastrointestinal tract. Gallbladder cancer preferentially metastasizes to regional lymph nodes and liver parenchyma. Bone metastasis from gallbladder carcinoma are rare presentation. In a study by Sameer $\mathrm{G}$ et al. ${ }^{[1]} 2.5 \%$ patients have cytologically proven skeletal metastasis. However, one autopsy series has reported about $10 \%$ incidence, which may indicate that the carcinoma gall bladder does metastasize to bone, perhaps in advanced stages ${ }^{[2]}$. To date there have only been a few case reports of bone metastasis in carcinoma gall bladder at the time of presentation. We report here two cases of gallbladder carcinoma with bony metastases.

\section{Case Report - 1}

A normotensive and nondiabetic male patient of age 30 year from Patna (India) presented to Mahavir Cancer Sansthan on $8^{\text {th }}$ January 2018 with complain of right hypochondrial pain and severe back pain for last 3 months. There is past history of lap cholecystectomy and appendicectomy on $26^{\text {th }}$ September 2017 outside for cholecystitis and appendicitis. Histopathology report was adenocarcinoma Grade II, scirrhous type with invasion into the serosa. He received one cycle of Gem + Cis based chemotherapy regimen outside (Last Date C1D8 - 25 - 122017).

PET CT (Fig: - 1) was done on 16 - 01- 2018 at our centre showing FDG avid (SUV max 9.71) enhancing soft tissue lesion in the operated bed 
abutting the adjacent liver parenchyma suggestive of local recurrence. Multiple FDG avid (SUV max 9.32) enhancing abdomino-pelvic soft tissue deposit - metastatic. FDG avid mediastinal \& abdominal nodes -? metastatic. FDG avid (SUV max 6.57) multiple mixed lytic-sclerotic skeletal lesions are seen in left femoral head, medial ends of left clavicle, C5, D8, D12, L1 \& L5 vertebrae, multiple sites in bilateral pelvic bones \& proximal end of right femur.

Palliative radiotherapy to D8-D12-L1 region was given in view of severe pain in back to a dose of $30 \mathrm{~Gy} / 10 \#$. Due to poor general condition single agent gemcitabine with zolendronic acid planned. He received cycle 1 chemotherapy on $10^{\text {th }}$ March 2018 thereafter he lost to follow up.

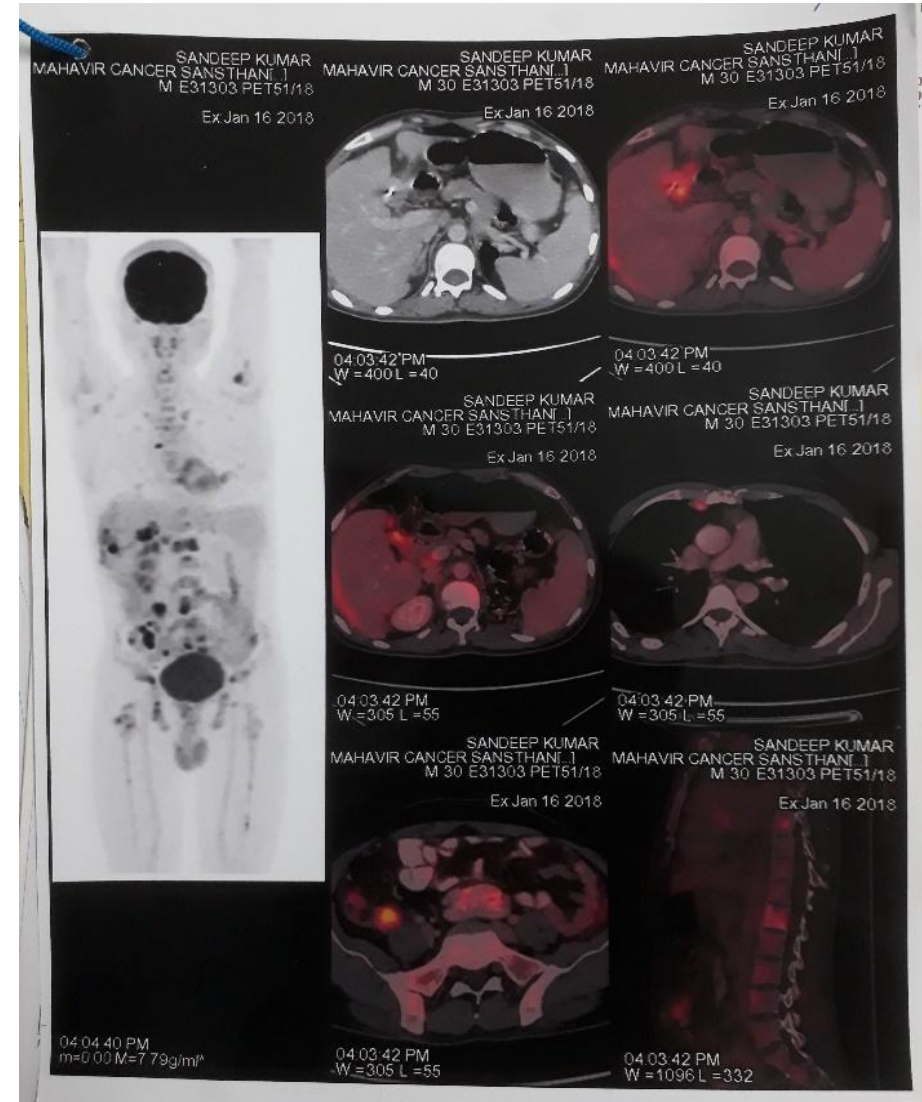

Fig: - 1 PET CT Scan showing local recurrence, abdomino-pelvic soft tissue deposit, mediastinal, abdominal nodes and multiple bony metastasis.

\section{Case Report - 2}

A 50-year-old female from Bhagalpur district (Bihar, India) presented to Mahavir Cancer Sansthan on $27^{\text {th }}$ March 2018 with complain of non-healing fracture of lower $3^{\text {rd }}$ of right humerus
(Fig - 2) after trivial trauma. Past history of nailing (Fig - 3) and POP cast outside on $24^{\text {th }}$ January 2018. F18-NaF positron Emission Tomography \& attenuation corrected CT scan $\left(3^{\text {rd }}\right.$ April 2018) report showed lytic destructive lesion in distal $3^{\text {rd }}$ of right humerus with prominent soft tissue component and metallic implant in situ. Attenuation correction images also show cortical erosion in middle $3^{\text {rd }}$ of left femoral shaft with increased tracer uptake and a gallbladder lesion. Ultrasound whole abdomen (29 ${ }^{\text {th }}$ March 2018) showed 27.9 x $26.5 \mathrm{~mm}$ size heterogeneous lesion in gallbladder fundal region with ill-defined gallbladder wall. Few periampullary nodal masses and mild ascites was also present. Ultrasound guided FNA from GB mass confirmed adenocarcinoma. Palliative radiotherapy (Fig - 4) to right shoulder and right elbow by Co-60 to a dose of $30 \mathrm{~Gy} / 10 \#$ given uneventfully. She was started on Gem + Cis + Zolendronic Acid based chemotherapy regimen, but after C3D1 chemotherapy on $10^{\text {th }}$ July 2018 she lost to follow up.

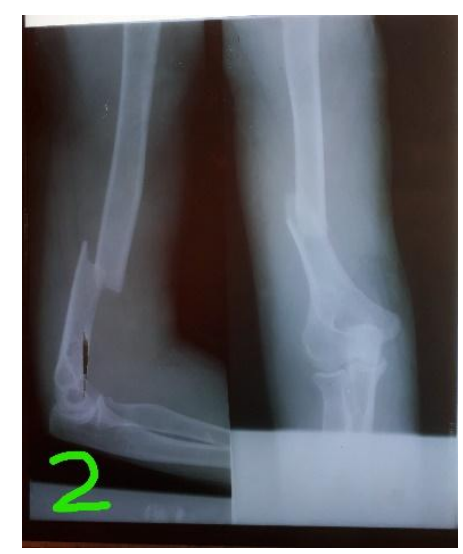

Fig 2: Plane x-ray showing fracture of right lower $3^{\text {rd }}$ of humerus

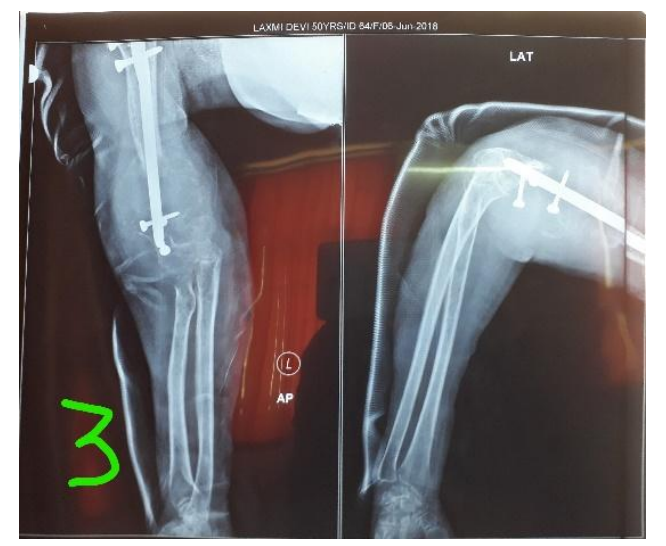

Fig 3: X-ray showing nailing of right humerus 


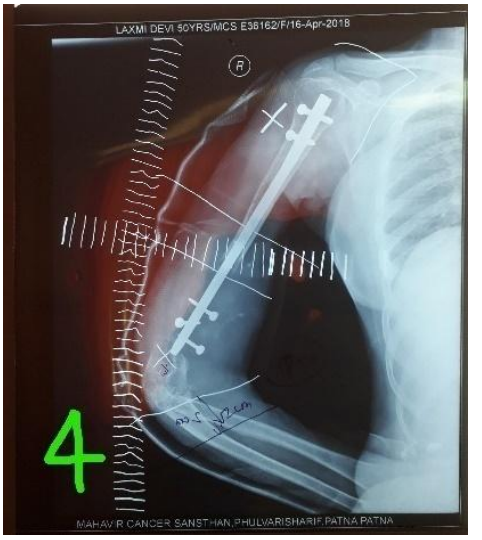

Fig 4: Radiotherapy planning x-ray

\section{Discussion}

In 1771, Maximillian de Stoll described the first case of a primary carcinoma of the gallbladder ${ }^{[3]}$. This cancer is characterised by local and vascular invasion, extensive regional lymph node metastasis and distant metastasis. Metastases occur most frequently to the liver (76-86\%), while regional lymph nodes are involved in about $60 \%$ of the cases. Metastases from gallbladder cancer occur to practically every organ including liver, lymph nodes, adrenal, kidney, spleen, brain, breast, thyroid, heart and uterus, those to the skeletal system are least frequent ${ }^{[4]}$. The incidence of bony metastasis is very rare and occurs only in the late stages of the disease, hence screening for bone metastasis is not routinely included in the workup of patients with carcinoma gallbladder. To our knowledge there are only 15 case reports of gallbladder carcinoma with skeletal metastasis in the English literature [Table - 1].

Table 1: Showing various case reports of carcinoma gallbladder with bony mets in English literature.

\begin{tabular}{|c|c|c|c|c|c|}
\hline & Author & Year & $\begin{array}{l}\text { No. of } \\
\text { cases }\end{array}$ & Site of bony metastasis & Presentation \\
\hline 1 & Kohli et al. 5 & 1994 & 1 & Femur & Pathological fracture \\
\hline 2 & Mishra et al. 6 & 1997 & 2 & Femur, $4^{\text {th }}$ lumber vertebra & $\begin{array}{l}\text { Pathological \#, Pain in } \\
\text { back, inability to walk }\end{array}$ \\
\hline 3 & Pandey et al. 7 & 1998 & 1 & Scalp & Scalp tumor \\
\hline 4 & A Kumar et al. 4 & 2003 & 1 & $\begin{array}{l}\text { Disseminated bony } \\
\text { metastasis }\end{array}$ & Generalized bony pain \\
\hline 5 & F. Youssef et al. 8 & 2003 & 1 & $\begin{array}{l}\text { Disseminated bony } \\
\text { metastasis }\end{array}$ & Bone pain \\
\hline 6 & Singh $\mathrm{S}$ et al. 2 & 2007 & 1 & Scalp & Scalp swelling \\
\hline 7 & Jain et al. 9 & 2009 & 1 & Humerus & $\begin{array}{l}\text { Pain \& restriction of } \\
\text { shoulder movement }\end{array}$ \\
\hline 8 & Kulkarni $\mathrm{M}$ et al. 10 & 2009 & 1 & Left scapula & $\begin{array}{l}\text { Dull aching pain in the } \\
\text { back }\end{array}$ \\
\hline 9 & Prakash $\mathrm{M}$ et al. 11 & 2010 & 2 & Sacrum / L1 vertebra & - \\
\hline 10 & Win AZ et al. 12 & 2013 & 1 & $\begin{array}{l}\text { Disseminated bony } \\
\text { metastasis }\end{array}$ & Back pain \\
\hline 11 & Joshi MK et al 13 & 2013 & 1 & C3/4 Vertebra & $\begin{array}{c}\text { Pain in neck, tenderness } \\
\text { over C4-C5, Sensory \& } \\
\text { motor deficit in right upper } \\
\text { limb (Power } 3 / 5)\end{array}$ \\
\hline 12 & Choudhary S et al. 14 & 2014 & 1 & Left greater trochanter & Pain in left hip joint \\
\hline 13 & A Joel et al. 15 & 2015 & 1 & $\begin{array}{c}\text { Thoracic / lumber } \\
\text { Vertebra }\end{array}$ & Generalized bony pain \\
\hline 14 & Yashwant A et al. 16 & 2016 & 2 & T11/Sacrum & Back pain, Low back pain \\
\hline 15 & Varshney VK et al. 17 & 2018 & 1 & $\begin{array}{l}\text { Ribs/Sternum/Vertebral } \\
\text { body }\end{array}$ & - \\
\hline 16 & Present case & 2018 & 2 & $\begin{array}{l}\text { Disseminated bony mets/ } \\
\text { right humerus fracture }\end{array}$ & $\begin{array}{l}\text { Back pain/ non-healing } \\
\text { fracture in right humerus }\end{array}$ \\
\hline
\end{tabular}

According to yochum and rowe ${ }^{[18]}$ among cases of skeletal metastases from the carcinoma of the gall bladder, $90 \%$ are purely osteolytic and $10 \%$ are mixed lytic and blastic type with purely osteoblastic lesions being unknown. In our first patient, there were multiple mixed lytic-sclerotic 
skeletal lesions but in second case, lytic destructive lesion in distal $3^{\text {rd }}$ of right humerus was present.

The management of patient with multifocal metastases is challenging. The role of chemotherapy in advanced disease is palliative without any significant survival benefit ${ }^{[19]}$. The primary aim of treatment in patients with metastatic disease is palliation of symptoms to help such patients live a quality life and let them die peacefully rather than agony from the advanced disease. In present both cases, bony metastases are treated by palliative radiotherapy. Due to poor general condition of my first patient, single agent weekly gemcitabine started but the patient after taking $1^{\text {st }}$ cycle chemotherapy lost to follow-up but the second patient having good health started on Gemcitabine + Cistplatin based chemotherapy and doing well. It will be interesting to see how this patient behaves in due course of time. However, the prognosis in these cases is unpredictable as very few cases have been reported.

\section{Conclusion}

Although rare, an occult gallbladder carcinoma may present with pathological fracture and/or severe bony pain due to metastasis. Early detection and prompt treatment would lead to better prognosis and improve the outcome.

Acknowledgement: I would like to express my special thanks \& gratitute to my teacher cum HOD Dr. Manisha Singh who regularly appriciating us for study and research work.

Conflicts of Interest: None

Source(s) of support: None

\section{References}

1. Sameer G., Naseem A., Vijay K. et al. Skeletal Metastasis in Gallbladder Cancer from a High-Volume Tertiary Care Center of North Inida: a Series of Rare Occurrence. J Gastrointest Canc (2015) 46: $36-41$
2. Shivendra Singh., et al. "Skeletal metastasis in gall bladder cancer". HPB (Oxford) 9.1 (2007): 71-72.

3. Arminski TC. Primary carcinoma of the gallbladder: a collective review with the addition of 25 cases from the Grace Hospital, Detroit, Michigan. Cancer 1949;2:379-98. doi:10.1002/10970142(194905)2:3<379::AIDCNCR2820020303>3.0.CO;2-Q.

4. Kumar A, Bhargava S K, Upreti L. Kumar J. Disseminated osteoblastic skeletal metastases from carcinoma of gallbladder - a case report, Indian J Radiol Imaging 2003;13:37-7

5. Kohli A, Chib RS, Parihar BK. Secondary involvement of femur in carcinoma of gall bladder. Indian J Cancer. 1994 Dec;31(4): 257-9.

6. Misra S, Chaturvedi A, Misra NC. Carcinoma gall bladder presenting with skeletal metastasis. Indian J Gastroenterol 1997;16:74.

7. Pandey M, Aryya NC, Pradhan S, Asthana AK, Gautam A, Shukla VK. Carcinoma of the gallbladder presenting as scalp tumour. Eur J Surg Oncol. 1998;24:605-7.

8. F Youssef, AW Khan, Br Davidson. Disseminated bony metastases following incidental gallbladder cancer detected after laparoscopic cholecystectomy. HPB (Oxford). 2003; 5(4): 258-260.

9. Jain G, Samaiya A, Mohindra N, Patel K. Bone metastasis as the initial presentation of carcinoma of gall bladder: A rarity. Indian J Surg. 2009;71:35-7.

10. Kulkarni M, Ramachandran V, Dash NR et al. Isolated Scapular Metastasis in a Patient with Gallbladder Carcinoma: Case Report. The Open Surgical Oncology Journal, 2009, 1, 10-11.

11. Prakash M, Aiyappan, Kumar A et ai. Solitary skeletal metastasis in carcinoma gallbladder: two case reports. Cancer Imaging. 2010; 10(1): 121-123. 
12. Win AZ, Aparici CM. Rare case of gallbladder cancer presenting with metastasis to bone and brain in an African American male discovered by F18-FDG PET/CT. J Biomed Graph Comput. 2013;3 (2):24-29.

13. Joshi MK, Joshi R, Chadha $M$ et al. Gall Bladder Carcinoma Presenting with Spinal Metastasis: A Rare Phenomenon. Indian J Palliat Care. 2013. May-Aug; 19(2): 113115.

14. Chaudhary S, Hatwal D, Bhat P. A Rare Presentation of gallbladder Carcinoma Metastasis. J Clin Diagn Res. 2014 June; 8(6): FD19-FD20.

15. Joel A, Samuel A, Bhatt A et al. Carcinoma of the gallbladder presenting with multiple osseous and inguinal lymph node metastases. Indian $\mathbf{J}$ Cancer 2015;52:230-1.

16. Yashant A, Priya H. Skeletal Metastasis From Carcinoma of the Gall bladder: Need for Bone Scintigraphy Justified? Pol J Radiol. 2016; 81: 206-208.

17. Varshney VK, Soni SC, Yadav $\mathrm{T}$ et al. Gall Bladder Carcinoma with Concurrent Metastases to Bone (Sclerotic) and Urinary Bladder. Journal of Clinical and Diagnostic Researsch. 2018 Jan. Vol12(1): PD06-PD08.

18. Yochum tr and rowel $\mathrm{j}$. tumor and tumor like processes. In: yochum tr and rowel $\mathrm{j}$, ed. Essentials of skeletal radiology. 1st edn. Baltimore, Maryland, USA. Williams and Wilkins, 1987; 975-1192.

19. Memon MA, Anwar S, Shiwani MH, Memon B (2005) Gallbladder carcinoma: a retrospective analysis of twenty-two years experience of a single teaching hospital. Int SeminSurg Oncol 17;2(1):63. 